\title{
CASCADE - The Circum-Arctic Sediment CArbon DatabasE
}

\author{
Jannik Martens ${ }^{1}$, Evgeny Romankevich ${ }^{2}$, Igor Semiletov ${ }^{3,4,5}$, Birgit Wild ${ }^{1}$, Bart van Dongen ${ }^{1,6}$, \\ Jorien Vonk ${ }^{1,7}$, Tommaso Tesi ${ }^{1,8}$, Natalia Shakhova ${ }^{3,9}$, Oleg V. Dudarev ${ }^{3}$, Denis Kosmach ${ }^{3}$, \\ Alexander Vetrov ${ }^{2}$, Leopold Lobkovsky², Nikolay Belyaev ${ }^{2}$, Robie W. Macdonald ${ }^{10}$, \\ Anna J. Pieńkowski ${ }^{11, a}$, Timothy I. Eglinton ${ }^{12}$, Negar Haghipour ${ }^{12}$, Salve Dahle ${ }^{13}$, Michael L. Carroll ${ }^{13}$, \\ Emmelie K. L. Åström ${ }^{14}$, Jacqueline M. Grebmeier ${ }^{15}$, Lee W. Cooper ${ }^{15}$, Göran Possnert ${ }^{16}$, and \\ Örjan Gustafsson ${ }^{1}$ \\ ${ }^{1}$ Department of Environmental Science and Bolin Centre for Climate Research, \\ Stockholm University, Stockholm, Sweden \\ ${ }^{2}$ Shirshov Institute of Oceanology, Moscow, Russia \\ ${ }^{3}$ Il'ichov Pacific Oceanological Institute FEB RAS, Vladivostok, Russia \\ ${ }^{4}$ Tomsk State University, Tomsk, Russia \\ ${ }^{5}$ Tomsk Polytechnic University, Tomsk, Russia \\ ${ }^{6}$ Department of Earth and Environmental Sciences and Williamson Research Centre for Molecular \\ Environmental Science, University of Manchester, Manchester, UK \\ ${ }^{7}$ Department of Earth Sciences, Vrije Universiteit Amsterdam, Amsterdam, the Netherlands \\ ${ }^{8}$ Institute of Polar Sciences, National Research Council, Bologna, Italy \\ ${ }^{9}$ Department of Chemistry, Moscow State University, Moscow, Russia \\ ${ }^{10}$ Institute of Ocean Sciences, Department of Fisheries and Oceans, Sidney, Canada \\ ${ }^{11}$ Department of Arctic Geology, The University Centre in Svalbard (UNIS), Svalbard, Norway \\ ${ }^{12}$ Laboratory of Ion Beam Physics and Geological Institute, ETH Zurich, Switzerland \\ ${ }^{13}$ Akvaplan-niva, FRAM - High North Research Centre for Climate and the Environment, Troms $\varnothing$, Norway \\ ${ }^{14}$ Department of Arctic and Marine Biology, UiT-The Arctic University of Norway, Troms $\varnothing$, Norway \\ ${ }^{15}$ Chesapeake Biological Laboratory, University of Maryland Center \\ for Environmental Science, Solomons, USA \\ ${ }^{16}$ Department of Physics and Astronomy, Tandem Laboratory, Uppsala University, Uppsala, Sweden \\ ${ }^{\mathrm{a}}$ current address: Norwegian Polar Institute, Longyearbyen, Svalbard, Norway
}

Correspondence: Örjan Gustafsson (orjan.gustafsson@aces.su.se)

Received: 22 December 2020 - Discussion started: 23 December 2020

Revised: 8 April 2021 - Accepted: 13 May 2021 - Published: 8 June 2021

Abstract. Biogeochemical cycling in the semi-enclosed Arctic Ocean is strongly influenced by land-ocean transport of carbon and other elements and is vulnerable to environmental and climate changes. Sediments of the Arctic Ocean are an important part of biogeochemical cycling in the Arctic and provide the opportunity to study present and historical input and the fate of organic matter (e.g., through permafrost thawing).

Comprehensive sedimentary records are required to compare differences between the Arctic regions and to study Arctic biogeochemical budgets. To this end, the Circum-Arctic Sediment CArbon DatabasE (CASCADE) was established to curate data primarily on concentrations of organic carbon $(\mathrm{OC})$ and $\mathrm{OC}$ isotopes $\left(\delta^{13} \mathrm{C}, \Delta^{14} \mathrm{C}\right)$ yet also on total $\mathrm{N}(\mathrm{TN})$ as well as terrigenous biomarkers and other sediment geochemical and physical properties. This new database builds on the published literature and earlier unpublished records through an extensive international community collaboration.

This paper describes the establishment, structure and current status of CASCADE. The first public version includes OC concentrations in surface sediments at 4244 oceanographic stations including 2317 with TN con- 
centrations, 1555 with $\delta^{13} \mathrm{C}$-OC values and 268 with $\Delta^{14} \mathrm{C}$-OC values and 653 records with quantified terrigenous biomarkers (high-molecular-weight $n$-alkanes, $n$-alkanoic acids and lignin phenols). CASCADE also includes data from 326 sediment cores, retrieved by shallow box or multi-coring, deep gravity/piston coring, or sea-bottom drilling. The comprehensive dataset reveals large-scale features of both OC content and OC sources between the shelf sea recipients. This offers insight into release of pre-aged terrigenous OC to the East Siberian Arctic shelf and younger terrigenous OC to the Kara Sea. Circum-Arctic sediments thereby reveal patterns of terrestrial OC remobilization and provide clues about thawing of permafrost.

CASCADE enables synoptic analysis of OC in Arctic Ocean sediments and facilitates a wide array of future empirical and modeling studies of the Arctic carbon cycle. The database is openly and freely available online (https://doi.org/10.17043/cascade; Martens et al., 2021), is provided in various machine-readable data formats (data tables, GIS shapefile, GIS raster), and also provides ways for contributing data for future CASCADE versions. We will continuously update CASCADE with newly published and contributed data over the foreseeable future as part of the database management of the Bolin Centre for Climate Research at Stockholm University.

\section{Introduction}

The Arctic Ocean receives large input of terrestrial organic matter from rivers and coastal erosion, making it a valuable receptor system for studying both large-scale terrestrial carbon remobilization and marine biogeochemistry. Rising temperatures cause multiple changes to the Arctic, including reduced sea-ice cover, accelerated erosion of icerich permafrost shorelines and enhanced river runoff, which changes the input of terrestrial organic matter to the Arctic Ocean (AMAP, 2017). This affects nutrients and the detrital load, the ocean optical field, marine primary productivity, ocean acidification and many other aspects of biogeochemical cycling (Stein and Macdonald, 2004; Vonk and Gustafsson, 2013). On land, climate change causes warming and thaw of terrestrial permafrost (Biskaborn et al., 2019), potentially remobilizing parts of its large dormant pool of OC (1300 Pg; Hugelius et al., 2014) into active carbon cycling. Rising temperatures may thus shift balances in the Arctic carbon cycle by transformation and translocation of previously frozen organic matter, which leads to system hysteresis effects and translocated carbon-climate feedback (e.g., Vonk and Gustafsson, 2013). Couplings between the large permafrost-carbon pools and amplified climate warming in the Arctic represent a potential "tipping point" in the climate system (Lenton, 2012). These perturbations may affect both OC sequestration in the biosphere and release of climateforcing greenhouse gases (e.g., AMAP, 2017; IPCC, 2019) as well as the coupling between permafrost carbon remobilization and ocean acidification across the extensive shelf seas (Semiletov et al., 2016).

Continental shelves cover less than $10 \%$ of the global ocean area but account for the largest part of OC accumulation in marine sediments and thereby provide an excellent archive for both terrestrial carbon input and marine productivity (Hedges et al., 1997). The Arctic Ocean is semienclosed and dominated by its extensive shelves, including the world's largest continental shelf system, the East
Siberian Arctic Shelf (ESAS; the Laptev, East Siberian and Russian part of the Chukchi Sea). This further accentuates the particular importance of shelf sediments for carbon cycling in the Arctic (Stein et al., 2004; Vetrov and Romankevich, 2004). Earlier landmark contributions have provided comprehensive observational perspectives on the distribution of organic matter in marine sediments at the global scale (e.g., Berner, 1982; Romankevich, 1984; Hedges and Keil, 1995). Focusing in greater detail on carbon in the Arctic, the book by Vetrov and Romankevich (2004) Carbon Cycle in the Russian Arctic Seas and the book edited by Stein and Macdonald (2004) The Organic Carbon Cycle in the Arctic Ocean provided the first more comprehensive perspectives on the Arctic land-ocean carbon couplings across various regions. Therein, the authors synthesized the collected knowledge of carbon sources, transformations and burial in Arctic marginal seas and the central Arctic Ocean. These compilations demonstrated substantial regional variations in carbon cycling between different Arctic shelf seas, while also acknowledging the near lack of observational data for key parameters and regions. Substantial progress has been made by individual and region-specific studies since then, with key advances in isotope and organic geochemistry that expand the variety of biogeochemical proxies to trace both sources and organic matter degradation. Stable carbon isotopes $\left(\delta^{13} \mathrm{C}-\mathrm{OC}\right)$ have been widely used to distinguish between marine and terrigenous sources in Arctic Ocean sediments (e.g., Naidu et al., 1993; Mueller-Lupp et al., 2000; Semiletov et al., 2005) and have since then been greatly supplemented by an expanded use of natural abundance radiocarbon $\left(\Delta^{14} \mathrm{C}-\mathrm{OC}\right)$. This has improved source apportionment of $\mathrm{OC}$ in bulk sediments across Arctic regions and timescales (e.g., Vonk et al., 2012; Goñi et al., 2013; Martens et al., 2020) and in sediment density fractions (Tesi et al., 2016b), in suspended particulate organic matter (e.g., Vonk et al., 2010, 2014; Karlsson et al., 2016), and at the molecular level (e.g., Drenzek et al., 2007; Gustafsson et al., 2011; Feng et al., 2013). Extensive studies of a wide set of molecular 
biomarkers (e.g., Fahl and Stein, 1997; Goñi et al., 2000; Belicka et al., 2004; Yunker et al., 2005; van Dongen et al., 2008; Tesi et al., 2014; Sparkes et al., 2015; Bröder et al., 2016) have provided growing insights into OC distribution and fate, particularly for terrigenous organic matter. Access to this growing number of observational data in a readily accessible interactive format would be greatly beneficial to wider system assessments and interpretations of organic matter in the Arctic Ocean.

The overarching objective of this effort is to curate and harmonize all available data on OC in Arctic Ocean sediments in an open and freely available database. The CircumArctic Sediment CArbon DatabasE (CASCADE) builds on previously published and unpublished collections holding information on $\mathrm{OC}$ and total $\mathrm{N}(\mathrm{TN})$ concentrations, as well as OC isotopes $\left(\delta^{13} \mathrm{C}-\mathrm{OC}, \Delta^{14} \mathrm{C}\right.$-OC) in sediments of all continental shelves and the deep central basins of the Arctic Ocean. Furthermore, CASCADE contains molecular data with an initial focus on terrestrial biomarkers (i.e., high-molecular-weight (HMW) $n$-alkanes, $n$-alkanoic acids, lignin phenols) to facilitate studies of terrestrial $\mathrm{OC}$ remobilization. The backbone of CASCADE is large data collections, including (i) $\mathrm{OC}$ concentrations, $\delta^{13} \mathrm{C} / \Delta^{14} \mathrm{C}$ isotope data and biomarkers from the informal 2-decadelong Swedish-Russian collaboration network the International Siberian Shelf Study (ISSS; Semiletov and Gustafsson, 2009) (e.g., Guo et al., 2004; Semiletov et al., 2005; van Dongen et al., 2008; Vonk et al., 2012; Tesi et al., 2016a; Bröder et al., 2018; Martens et al., 2019, 2020; Muschitiello et al., 2020); (ii) OC concentrations from the Arctic portion of the "Carbon Database" of the Shirshov Institute of Oceanology, Russian Academy of Sciences (Romankevich, 1984; Vetrov and Romankevich, 2004); (iii) previously published databases and online collections (e.g., https://pangaea.de/) with many contributions from German-Russian partnerships and cruises involving the Alfred Wegener Institute, Germany (e.g., Stein et al., 1994; Mueller-Lupp et al., 2000; Stein and Macdonald, 2004; Xiao et al., 2015); (iv) US and Canadian research (e.g., Naidu et al., 1993, 2000; Goñi et al., 2000, 2013; Grebmeier et al., 2006); and (v) data from various other contributors that are acknowledged in the database. The initial version also includes previously unpublished data, with some generated here in the upstart of CASCADE, to fill gaps for particularly data-lean regions such as the Barents and Kara seas, the Canadian Arctic Archipelago, and the Chukchi Sea.

The aim of the CASCADE effort is to provide a foundation for future studies. These may include large-scale assessments of the carbon cycle, such as characteristics of OC input, and its distribution and fate in the Arctic Ocean. This paper describes the creation and the structure of CASCADE, including a discussion of data availability and quality.

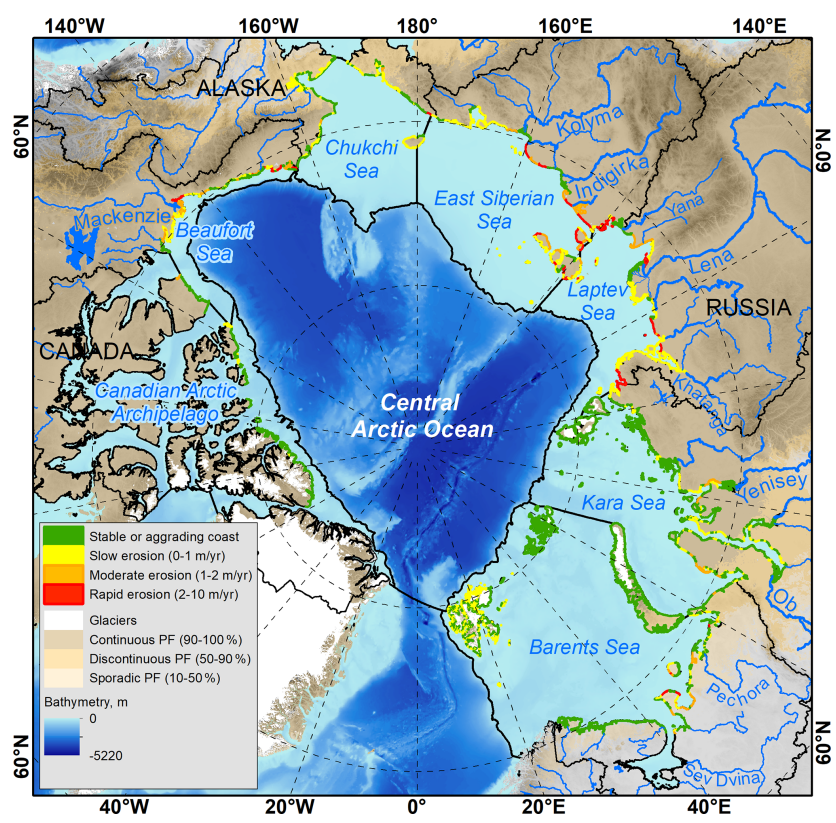

Figure 1. Overview map of the Arctic Ocean compartments defined and used in CASCADE, with the permafrost distribution based on numerical modeling (Obu et al., 2019), rates of coastal erosion (Lantuit et al., 2012) and the latest IBCAO v4 bathymetry (Jakobsson et al., 2020). Black lines delineate the extent of the Arctic Ocean shelf seas and each respective watershed on land.

\section{Data collection and methods}

\subsection{The physical compartments: Arctic shelf seas and interior Arctic Ocean basins}

CASCADE includes OC data from the entire Arctic Ocean with special focus on the seven Arctic continental shelf seas (Fig. 1; Table 1). Accordingly, a distinction is made among the central Arctic Ocean and the following marginal seas: Beaufort Sea, Chukchi Sea, East Siberian Sea, Laptev Sea, Kara Sea, Barents Sea (including White Sea) and the Canadian Arctic Archipelago (we exclude data from Baffin Bay, Foxe Basin and Hudson Bay, as they are outside the circumArctic scope of the database). For defining the limits of these Arctic shelf seas, Jakobsson (2002) is followed, which distinguishes the Arctic Ocean constituent seas using hypsometric criteria. Therein, shelf is defined as the seaward extension of the continental margin until the increase in steepness at the shelf break (Jakobsson, 2002). Data for the central Arctic Ocean were treated as one individual unit that covers all area beyond the shelf break and includes the continental slope, rise, deep basins and mid-ocean ridges.

\subsection{Georeferencing and sampling}

The coordinate system used for CASCADE is WGS1984, and coordinates are kept in machine-readable decimal degrees (latitude in ${ }^{\circ} \mathrm{N}$, longitudes in the -180 to $180^{\circ}$ format) 
Table 1. CASCADE data availability per circum-Arctic shelf sea and for the interior basin.

\begin{tabular}{|c|c|c|c|c|c|c|c|c|c|c|c|c|c|}
\hline \multicolumn{2}{|c|}{ Shelf area } & \multirow{2}{*}{$\begin{array}{r}\begin{array}{r}\text { Area } \\
10^{3} \mathrm{~km}^{2}\end{array} \\
1626\end{array}$} & \multirow{2}{*}{$\begin{array}{r}\text { OC } \\
n \\
1092\end{array}$} & \multirow{2}{*}{$\frac{\mathrm{TN}}{353}$} & \multirow{2}{*}{$\begin{array}{r}\delta^{13} \mathrm{C} \\
n \\
236\end{array}$} & \multirow{2}{*}{$\begin{array}{r}\text { New } \\
\delta^{13} \mathrm{C} \\
n\end{array}$} & \multirow{2}{*}{$\begin{array}{r}\Delta^{14} \mathrm{C} \\
n \\
33\end{array}$} & \multirow{2}{*}{$\begin{array}{r}\text { New } \\
\Delta^{14} \mathrm{C} \\
n\end{array}$} & \multirow{2}{*}{$\begin{array}{r}\text { Alk } 1^{1} \\
n \\
0\end{array}$} & \multirow{2}{*}{$\begin{array}{r}\mathrm{Alk} 2^{2} \\
n \\
13\end{array}$} & \multirow{2}{*}{$\begin{array}{r}\text { Acid }^{3} \\
n \\
0\end{array}$} & \multirow{2}{*}{$\begin{array}{r}\text { Lignin }^{4} \\
n \\
0\end{array}$} & \multirow{2}{*}{$\begin{array}{r}\text { New } \\
\text { lignin } \\
n \\
0\end{array}$} \\
\hline 1 & Barents Sea ${ }^{5}$ & & & & & & & & & & & & \\
\hline 2 & Kara Sea & 942 & 637 & 201 & 262 & 22 & 29 & 22 & 2 & 90 & 2 & 0 & 0 \\
\hline 3 & Laptev Sea & 505 & 312 & 110 & 214 & 8 & 42 & 14 & 33 & 46 & 31 & 36 & 19 \\
\hline 4 & East Siberian Sea & 1000 & 259 & 217 & 187 & 17 & 71 & 16 & 28 & 13 & 10 & 68 & 40 \\
\hline 5 & Chukchi Sea & 639 & 1084 & 950 & 256 & 9 & 12 & 10 & 67 & 14 & 58 & 3 & 0 \\
\hline 6 & Beaufort Sea & 183 & 247 & 122 & 219 & 5 & 32 & 3 & 5 & 1 & 2 & 11 & 0 \\
\hline 7 & Canadian Arctic Archipelago 6 & 1171 & 92 & 87 & 55 & 29 & 22 & 19 & 0 & 0 & 0 & 9 & 0 \\
\hline \multirow[t]{2}{*}{8} & Central Arctic Ocean ${ }^{7}$ & 4500 & 529 & 282 & 130 & 15 & 27 & 10 & 29 & 36 & 28 & 18 & 5 \\
\hline & Total & 10566 & 4252 & 2322 & 1559 & 153 & 268 & 127 & 164 & 213 & 131 & 145 & 64 \\
\hline
\end{tabular}

to harmonize the data across all GIS applications. The collection of data from oceanographic stations is the main part of CASCADE and is organized in a table format that contains columns for the station number ("STATION") and geographical coordinates ("LAT"; "LON"). The spatial references also include information about the sediment depth interval that reported data represent ("UPPERDEPTH'; "LOWERDEPTH"), where the upper depth is equal to $0 \mathrm{~cm}$ in the case of surface sediments. In addition, the table contains a column for water depth ("WATERDEPTH") as reported by the data source. In cases where the water depth was not reported, the water depth was estimated using the latest version (v4) of the bathymetric map of IBCAO (Jakobsson et al., 2020) corresponding to the position of the oceanographic station and reported in a separate column ("IBCAODEPTH"). Furthermore, the name of the expedition and/or ship ("EXPEDITION") and the year when the sample was taken ("YEAR") are reported. For samples where the sampling year was unknown, users may use the year of publication instead.

\subsection{Surface sediments and sediment cores}

The first stage of the CASCADE development focused on maximizing spatial coverage for surface sediments of the seven circum-Arctic shelf sea systems and the central Arctic Ocean. Here, surface sediments are defined as those collected from the water-sediment interface to a depth of maximum $5 \mathrm{~cm}$. Data for surface sediments are provided in a table ("CASCADEsurfsed") as .txt and .xlsx files and in a ready-to-use GIS shapefile format. This database also includes deeper sediments from sediment cores, which represent longer timescales and add a third dimension to the geographical referencing. Types of sediment cores are distinguished in CASCADE such that different biogeochemical processes, acting on three depositional timescales, may be addressed. The three timescales are
1. centennial scale cores (core scale 1) in upper sediments of the Arctic Ocean, e.g., multi-corer, Gemini corer, box corer, van Veen grab sampler, other short gravity corers up to $1 \mathrm{~m}$ length;

2. millennial scale cores (core scale 2) of shelf sediments roughly covering the depositional time frame from the late Holocene to the last glacial-interglacial transition, by piston corer, long gravity corer and kasten corer; and

3. glacial cycle scale cores (core scale 3 ) from the continental slopes or the deeper Arctic Ocean basins covering periods from earlier than the Last Glacial Maximum, including drill coring on the circum-Arctic shelves or deep-sea piston cores.

Downcore data are stored in three separate data tables ("CASCADEcorescale1"; "CASCADEcorescale2"; "CASCADEcorescale3") in addition to the surface sediment files, including a column for the sampling depth of core subsamples in centimeters below the sediment surface ("COREDEPTH").

\subsection{Database parameters}

CASCADE contains information about the concentration and isotopic and molecular composition of $\mathrm{OC}$ in marine Arctic sediments. In addition to (i) OC concentrations (column "OC"), the database includes (ii) concentrations of TN ("TN") and (iii) the gravimetric ratio of $\mathrm{OC} / \mathrm{TN}$ ("OC / TN"), which may provide additional information about the organic matter source (e.g., Goñi et al., 2005; van Dongen et al., 2008). Furthermore, CASCADE contains data of (iv) $\delta^{13} \mathrm{C}-\mathrm{OC}$ ("d13C") as a parameter to distinguish between marine and terrestrial sources (e.g., Fry and Sherr, 1989 ) and (v) $\Delta^{14} \mathrm{C}-\mathrm{OC}$ ("D14C") to assess the presence of aged organic matter released from permafrost deposits (e.g., Gustafsson et al., 2011; Vonk et al., 2012) or from petrogenic sources such as sedimentary rocks (e.g., Yunker et al., 2005; 
Goñi et al., 2013) in marine sediments. More details about the CASCADE parameters and their units are provided in Table 2.

Data of terrigenous biomarkers may facilitate further investigations of terrigenous OC input (Table 2). The first version of CASCADE compiles total concentrations of $n$ alkanes with high molecular weight (HMW) and $\mathrm{C}_{21}-\mathrm{C}_{31}$ carbon atoms $\left(\sum \mathrm{C}_{21}-\mathrm{C}_{31}\right.$; column "HMWALK"), as well as the often separately reported more specific $n$-alkanes $\sum \mathrm{C}_{27}+\mathrm{C}_{29}+\mathrm{C}_{31}$ ("HMWALK_SPEC"). CASCADE also contains the sum of the HMW $n$-alkanoic acids $\sum \mathrm{C}_{20}-\mathrm{C}_{30}$ ("HMWACID"). Both compound classes stem mostly from terrigenous compartments as they derive from epicuticular leaf waxes of land plants with a typical pattern of dominating odd-numbered homologues for HMW $n$-alkanes and evennumbered homologues for HMW $n$-alkanoic acids (Eglinton and Hamilton, 1967). Furthermore, the database holds concentrations of lignin phenols ( $\sum$ syringyl, vanillyl, cinnamyl; "LIGNIN"), which are products from the break-up of the lignin biopolymer, a compound only produced by vascular plants (Hedges and Mann, 1979). These three compound classes are frequently used as tracers of the sources and fate of terrestrial organic matter sequestered in Arctic Ocean sediments (Fahl and Stein, 1997; Goñi et al., 2000; Tesi et al., 2014; Bröder et al., 2016). It is recognized that there are more parameters that could be included, and CASCADE can add further extensions in future versions.

\subsection{Reference to the original publication}

Each data source added to CASCADE is fully cited (in the formatting style of Earth Systems Science Data; ESSD) to maintain a high level of transparency. When applicable, citations also include a digital object identifier (DOI) that is linked to the reference in the primary literature next to each parameter column. Accordingly, the CASCADE data sheet distinguishes between a common reference for OC, TN and OC / TN data ("CN_CITATION") as they are often combined in one measurement and separate references for OC isotopes (“d13C_CITATION"; "D14C_CITATION") and concentrations of biomarkers ("BM_CITATION"). This facilitates registration of multiple measurements based on the same or split sediment sample material for individual oceanographic stations. A full list of references is separately provided on the CASCADE website and in the Supplement of this paper.

\subsection{Data source and quality}

A part of CASCADE builds on previous separate and partly inaccessible databases of OC parameters that key partners of the CASCADE consortium and others have collected over the years. This includes data from the informal Swedish-Russian collaboration network called the International Siberian Shelf Study (ISSS; Semiletov and Gustafs- son, 2009) and the "Carbon" database of the Shirshov Institute of Oceanology. This basis for CASCADE was strengthened by an extensive survey of the peer-reviewed literature and data mining in the grey literature of scientific cruise reports. To facilitate quality assurance criteria by the end users, the database also records metadata (e.g., sampling technique in the field, sample storage) and quality data when available. The quality assurance information for data in CASCADE is as follows.

- Data need to be (geo-)referenceable and located in the target region (i.e., the Arctic Ocean).

- Information about the analysis method is provided by the data source.

- For OC concentrations, values were generated by elemental analyzer (EA) or Rock-Eval pyrolysis and reported as weight- $\%$ OC. Total $\mathrm{N}$ concentrations and $\mathrm{OC} / \mathrm{TN}$ ratios are based on EA only.

- For $\delta^{13} \mathrm{C}-\mathrm{OC}$, data stored in CASCADE are based on isotope ratio mass spectrometry (IRMS), often coupled to an EA and calibrated against the PDB/V-PDB analytical standards.

- For $\Delta^{14} \mathrm{C}$-OC, the measurements of ${ }^{14} \mathrm{C}$ data are based on mass spectrometry with ${ }^{14} \mathrm{C}$ data reported as $\Delta^{14} \mathrm{C}$, with fraction of modern $\left(F_{\mathrm{m}}\right)$ or conventional ${ }^{14} \mathrm{C}$ age in the original publication. We also kept records of the ${ }^{14} \mathrm{C} / \mathrm{AMS}$ lab code of the sample if given.

- Terrigenous biomarker analysis was carried out by solvent extraction (for HMW $n$-alkanes and $n$-alkanoic acids) or by alkaline $\mathrm{CuO}$ oxidation of the lignin biopolymer (for lignin phenols) of the sediments, followed by wet chemistry purification and quantification using gas chromatography analysis with either flame ionization or mass spectrometry detection.

In addition to the abovementioned information, the aim was also to include information about carbonate removal by acid treatment prior to the measurement of $\mathrm{OC}, \delta^{13} \mathrm{C}$ OC and $\Delta^{14} \mathrm{C}$-OC. However, details about applied procedures were missing in most cases, and it is therefore assumed that the carbonate fraction was removed from total carbon prior to $\mathrm{OC}, \delta^{13} \mathrm{C}-\mathrm{OC}$ and $\Delta^{14} \mathrm{C}$-OC measurements. All meta-information (sampling, storage, analysis) for each CASCADE entry is included in a respective column in the data spreadsheet (Table 2).

\subsection{New gap-filling analyses}

\subsubsection{Bulk OC and carbon isotopes}

Gap filling was performed in surface sediments of regions with particularly poor data density. These efforts thus focused on areas north of western Siberia (Barents and Kara 
Table 2. Parameter description and name of the respective columns in the CASCADE data sheet.

\begin{tabular}{|c|c|c|}
\hline Parameters & Description & Column name \\
\hline CASCADE entry ID & Serial number & ID \\
\hline \multicolumn{3}{|l|}{ Georeference and sampling information } \\
\hline Sample code & Expedition station ID & STATION \\
\hline Latitude & Decimal latitude according to WGS1984 & LAT \\
\hline Longitude & Decimal longitude according to WGS1984 & LON \\
\hline Upper sample depth $(\mathrm{cm})$ & Sample depth (for surface sediments only) & UPPERDEPTH \\
\hline Lower sample depth $(\mathrm{cm})$ & Sample depth (for surface sediments only) & LOWERDEPTH \\
\hline Median sample depth $(\mathrm{cm})$ & Median sample depth (for core samples only) & COREDEPTH \\
\hline Water depth (m b.s.1.) & Water depth of sampling according to shipboard measurement & WATERDEPTH \\
\hline Water depth based on IBCAO (m b.s.1.) & Water depth according to IBCAOv4 & IBCAODEPTH \\
\hline Expedition or vessel name & Vessel name, expedition name, cruise number & EXPEDITION \\
\hline Sampling year & Year when the sample was taken as reported in literature & YEAR \\
\hline \multicolumn{3}{|l|}{ Carbon and nitrogen $(\mathrm{CN})$ data } \\
\hline $\mathrm{OC}(\%)$ & $\begin{array}{l}\text { Total OC concentration of the bulk sediment; } \\
\text { carbonate removal assumed }\end{array}$ & $\mathrm{OC}$ \\
\hline $\mathrm{TN}(\%)$ & Total $\mathrm{N}$ concentration of the bulk sediment & $\mathrm{TN}$ \\
\hline $\mathrm{OC} / \mathrm{TN}$ & OC / TN ratio (gravimetric); published values or calculated & OC_TN \\
\hline \multicolumn{3}{|l|}{ Carbon isotopes } \\
\hline$\delta^{13} \mathrm{C}(\% \circ \mathrm{VPDB})$ & $\delta^{13} \mathrm{C}-\mathrm{OC}$; carbonate removal assumed & $\mathrm{d} 13 \mathrm{C}$ \\
\hline$\Delta^{14} \mathrm{C}(\% \circ)$ & $\Delta^{14} \mathrm{C}$-OC corrected for age; carbonate removal assumed & $\mathrm{D} 14 \mathrm{C}$ \\
\hline \multicolumn{3}{|l|}{ Biomarkers } \\
\hline$n$-alkanes $\mathrm{C}_{21-31}\left(\mu \mathrm{gg}^{-1} \mathrm{OC}\right)$ & OC-normalized concentration of HMW $n$-alkanes & HMWALK \\
\hline$n$-alkanes $\mathrm{C}_{27,29,31}\left(\mu \mathrm{gg}^{-1} \mathrm{OC}\right)$ & OC-normalized concentration of specific HMW $n$-alkanes & HMWALK_SPEC \\
\hline$n$-alkanoic acids $C_{20-30}\left(\mu \mathrm{g} \mathrm{g}^{-1} \mathrm{OC}\right)$ & OC-normalized concentration of HMW $n$-alkanoic acids & HMWACID \\
\hline Lignin phenols ( $\left.\mathrm{mg} \mathrm{g}^{-1} \mathrm{OC}\right)$ & OC-normalized concentration of syringyl, vanillyl, cinnamyl & LIGNIN \\
\hline \multicolumn{3}{|l|}{ Quality parameter and meta information } \\
\hline Sediment sampler & Method of sediment sampling & SAMPLER \\
\hline Sample storage & 0: unknown; 1 : frozen; 2: refrigerated; 3 : dried on board & STORAGE \\
\hline $\mathrm{CN}$ measurement & Description of the method of analysis of the OC and TN data & CN_METHOD \\
\hline$\delta^{13} \mathrm{C}$ measurement & Description of the method of analysis of $\delta^{13} \mathrm{C}-\mathrm{OC}$ & d13C_METHOD \\
\hline $\mathrm{AMS} /{ }^{14} \mathrm{C}$ label & Laboratory number of the $\Delta^{14} \mathrm{C}$ measurement & D14C_LABEL \\
\hline \multicolumn{3}{|l|}{ Citation of the data source } \\
\hline Citation of $\mathrm{CN}$ data & Full citation in $E S S D$ style including info about publication format & CN_CITATION \\
\hline Citation of $\delta^{13} \mathrm{C}$ data & Authors, title, journal, volume, pages, DOI, year & d13C_CITATION \\
\hline Citation of $\Delta^{14} \mathrm{C}$ data & Full citation in ESSD style including info about publication format & D14C_CITATION \\
\hline Citation of biomarker data & Full citation in $E S S D$ style including info about publication format & BM_CITATION \\
\hline
\end{tabular}

Sea region) and in the Canadian Arctic Archipelago, using archived sample material that was provided by CASCADE collaborators. For OC, TN and $\delta^{13} \mathrm{C}-\mathrm{OC}$ analysis, about $10 \mathrm{mg}$ each of a total of 153 freeze-dried sediment samples was weighed in silver capsules and acidified drop-wise with $3 \mathrm{M} \mathrm{HCl}$ in order to remove carbonates. The measurement was carried out using a Carlo Erba NC2500 elemental analyzer coupled to an isotope-ratio mass spectrometer (Finnigan DeltaV Advantage) in the Department of Geologi- cal Sciences, Stockholm University, with $\pm 3 \%$ precision for $\mathrm{OC}$ analysis and $\pm 0.15 \%$ precision for $\delta^{13} \mathrm{C}$-OC isotopic measurements.

Furthermore, a subset of 95 samples was selected for gapfilling bulk-level $\Delta^{14} \mathrm{C}-\mathrm{OC}$ analysis at the Tandem Laboratory, Department of Physics, Uppsala University. A sample amount corresponding to $1 \mathrm{mg}$ OC was weighed in tin capsules and acidified with $3 \mathrm{M} \mathrm{HCl}$ to remove carbonates. Samples with low OC concentrations $(<0.5 \%)$ were placed in 
small beakers and exposed to acid fumes in a desiccator for $24 \mathrm{~h}$ to remove carbonates and combusted to $\mathrm{CO}_{2}$ in evacuated quartz tubes prior to graphitization at the ${ }^{14} \mathrm{C} / \mathrm{AMS}$ laboratory. An additional set of 30 gap-filling samples was analyzed for $\Delta^{14} \mathrm{C}$ at the ${ }^{14} \mathrm{C}$ laboratory of ETH Zurich after acid fumigation. The measurements at Uppsala University had a precision of on average $\pm 1.9 \%$ while the precision at ETH Zurich was on average $\pm 1.1 \%$ (based on ${ }^{14} \mathrm{C}$ counting statistics).

In CASCADE, all new data points are labeled by citing the database (Martens et al., 2021, https://doi.org/10.17043/cascade) in the respective reference columns.

\subsubsection{Analysis of lignin phenols}

Gap-filling analysis was also performed for lignin phenols as molecular biomarkers for terrestrial organic matter using a set of 64 samples from data-lean regions. To extract lignin phenols from marine sediments, we applied an alkaline $\mathrm{CuO}$ oxidation protocol using a microwave-based method as originally presented by Goñi and Montgomery (2000) and followed the same laboratory routine as described in greater detail elsewhere (Tesi et al., 2014; Martens et al., 2019).

\subsection{Data conversion and harmonization}

Recalculations of literature data (e.g., for unit conversions) were in some cases necessary to harmonize the data to the standard units as defined in Table 2.

In CASCADE the concentration of OC is reported in percent $(\%)$ of the dry weight; values previously published as milligrams of OC per gram of dry weight were divided by a factor of 10 .

CASCADE uses ${ }^{14} \mathrm{C}$ with age correction (Eq. 1) to report the activity of radiocarbon according to convention (Stuiver and Polach, 1977; Stenström et al., 2011). For radiocarbon values that were reported as conventional ${ }^{14} \mathrm{C}$ ages we used Eq. (2) to calculate the age-corrected $\Delta^{14} \mathrm{C}$.

$$
\begin{aligned}
& \Delta^{14} \mathrm{C}=\left(F_{\mathrm{m}} \cdot e^{\lambda_{\mathrm{C}}\left(1950-Y_{\mathrm{C}}\right)}-1\right) \cdot 1000 \% \\
& \Delta^{14} \mathrm{C}=\left(e^{-\lambda_{\mathrm{L}} \cdot T_{14_{\mathrm{C}} \text {-years }}} \cdot e^{\lambda_{\mathrm{C}}\left(1950-Y_{\mathrm{C}}\right)}-1\right) \cdot 1000 \%
\end{aligned}
$$

Here $F_{\mathrm{m}}$ is the fraction modern, $\lambda_{\mathrm{C}}$ the decay constant of the Cambridge half-life of ${ }^{14} \mathrm{C}\left(T_{1 / 2-\mathrm{C}}=5730 ; \lambda_{\mathrm{C}}=1 / 8267\right)$, $Y_{\mathrm{C}}$ the year of sample collection, $\lambda_{\mathrm{L}}$ the decay constant of the Libby half-life of ${ }^{14} \mathrm{C}\left(T_{1 / 2-\mathrm{L}}=5568 ; \lambda_{\mathrm{C}}=1 / 8033\right)$ and $T_{14} \mathrm{C}$-years the conventional ${ }^{14} \mathrm{C}$ age (Stuiver and Polach, 1977).

All biomarker concentrations of HMW $n$-alkanes and $n$ alkanoic acids are reported as micrograms per gram of OC while lignin phenols are reported as milligrams per gram of OC. Biomarker concentrations that in the original publication were reported as normalized to dry sediment weight were

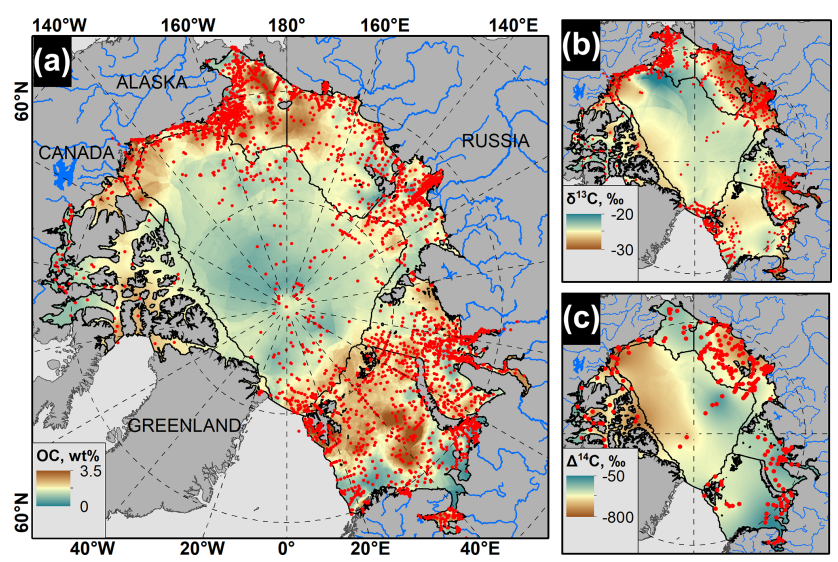

Figure 2. CASCADE data location for OC concentrations (a). Carbon isotopes $\delta^{13} \mathrm{C}(\mathbf{b})$ and $\Delta^{14} \mathrm{C}(\mathbf{c})$ marked as red dots, with interpolated fields as indicated by the inserted color scale and as described in the main text.

for CASCADE normalized to the OC concentration of the sample.

\subsection{Data interpolation}

CASCADE provides interpolated files (GEOtiff, ASCII; coordinate system WGS 1984 Arctic Polar Stereographic) for OC content, $\delta^{13} \mathrm{C}-\mathrm{OC}$ and for $\Delta^{14} \mathrm{C}$-OC in surface sediments across the Arctic Ocean. OC data were mapped in ArcGIS 10.6 and interpolated to a resolution of $5 \times 5 \mathrm{~km}$ per grid cell using the empirical Bayesian kriging function (EBK; Gribov and Krivoruchko, 2020) in the commercially available ArcGIS 10.8 software package (ESRI). Kriging builds on the assumption that two points located in proximity are more similar than two points further apart and creates a gridded surface of predicted values using an empirical semivariogram model. As an advancement to kriging, EBK repeatedly simulates semivariogram models in subsets of up to 200 data points and thus not only improves the prediction but also optimizes interpolation across areas with strongly varying data availability in the Arctic Ocean (e.g., shelf seas vs. central basins).

\section{Results and discussion}

\subsection{Dataset inventory}

Surface sediments show by far the largest data availability. The dataset of OC concentrations in CASCADE includes 4244 different locations across the Arctic Ocean (Fig. 2), while the concentration of $\mathrm{TN}$ and the $\mathrm{OC} / \mathrm{TN}$ ratio are known for 2317 locations (Table 1). For carbon isotopes, the number of individual $\delta^{13} \mathrm{C}-\mathrm{OC}$ values is 1555 , and for $\Delta^{14} \mathrm{C}-\mathrm{OC}$ it is 268. CASCADE also holds concentrations of terrigenous biomarkers at 131-213 locations per compound group. Most of the biomarker data are for HMW $n$-alkanes, 
with either concentrations of HMW $n$-alkanes $\left(\sum \mathrm{C}_{21}-\mathrm{C}_{31}\right.$; 213 stations) or chain lengths more specific for higher plants $\left(\sum \mathrm{C}_{27}, \mathrm{C}_{29}, \mathrm{C}_{31} ; 164\right)$. Fewer data are available for concentrations of HMW $n$-alkanoic acids $\left(\sum \mathrm{C}_{20}-\mathrm{C}_{30} ; 131\right)$ and the concentrations of lignin phenols (145).

In addition to surface sediments, a total number of 326 sediment cores (79 centennial, 229 millennial and 18 glacial cycle scale cores) are included in the first version of CASCADE. Combined, these hold another 10552 observations of OC concentrations, 4769 concentrations of TN and 2122 $\delta^{13} \mathrm{C}-\mathrm{OC}$ ratios in core samples from across the Arctic Ocean.

\subsection{Spatial distribution of data}

The data coverage for surface sediments is highly variable among the shelf seas, yet improved by the extensive gapfilling analysis (Table 1). The largest number of OC concentrations is in the Barents Sea (1092; Table 1). Despite the large total number of available Arctic sediment $\mathrm{OC}$ concentrations, there are only 236 samples analyzed for $\delta^{13} \mathrm{C}$-OC and 33 with $\Delta^{14} \mathrm{C}-\mathrm{OC}$ in the Barents Sea, and of these most are located in the Norwegian (western) sector of the Barents Sea. For the eastern Siberian Arctic and the North American sector of the Arctic Ocean, observations of OC concentrations are lower, but the availability of $\delta^{13} \mathrm{C}-\mathrm{OC}$ data is higher (Table 1, Fig. 2b, c). Accordingly, the Kara, Laptev, East Siberian and Chukchi seas each support more than 200 $\delta^{13} \mathrm{C}$-OC observations. The number of $\Delta^{14} \mathrm{C}$-OC observations is generally lower but reveals the highest coverage in near-coastal areas, with 28 values in the Kara Sea, 42 values in the Laptev Sea and 71 values in the East Siberian Sea. Data availability in the Chukchi Sea for $\Delta{ }^{14} \mathrm{C}$-OC is lower $(n=12)$, stressing the need for future analysis. The lowest availability of data is in the Canadian Arctic Archipelago. Gap-filling analysis of OC here increased the number of OC concentrations from 21 to 54, with a similar number for carbon isotopes (51 of $\delta^{13} \mathrm{C}$-OC; 22 of $\Delta^{14} \mathrm{C}$-OC) distributed over its vast area of $1171000 \mathrm{~km}^{2}$. The largest individual regime area is covered by the interior basins of the central Arctic Ocean, which holds 529 observations of OC concentrations, 130 of $\delta^{13} \mathrm{C}-\mathrm{OC}$ and 27 of $\Delta^{14} \mathrm{C}-\mathrm{OC}$ values.

\subsection{Assessment of data quality}

Based on the quality assurance data available, CASCADE provides detailed information about the techniques involved in analyzing OC concentrations, isotopes and biomarkers. The development of CASCADE included the collection of meta-information about sampling, storage and analysis, as described in Sect. 2.6. This information is included and detailed in CASCADE. The quality assurance information shows that $86 \%$ of the reported OC concentrations were analyzed using EA, and only a minority were analyzed by RockEval pyrolysis. For $\delta^{13} \mathrm{C}-\mathrm{OC}$, in $66 \%$ of the cases IRMS cou- pled to EA was reported as the method of analysis. Regarding sample storage, information was given in about $59 \%$ of all data sources that the samples were kept frozen between sampling and analysis, while for $<1 \%$ of the cases it was documented that the samples were stored refrigerated; this means that for $40 \%$ of the samples, there was no information provided about sample storage. For $78 \%$ of the $\Delta^{14} \mathrm{C}$ OC values, the laboratory ${ }^{14} \mathrm{C} / \mathrm{AMS}$ label was documented and thus also added to the CASCADE sheet.

\subsection{Circum-Arctic carbon features}

Visualization of CASCADE data directly reveals several large-scale features of OC in Arctic Ocean sediments. These include clear differences in both OC concentration and source-diagnostic isotope composition among the shelf seas. For instance, interpolated OC concentrations (Fig. 2) indicate that high sedimentary OC content is found both in regions of high terrestrial input (e.g., Kara Sea, Laptev Sea, East Siberian Sea and Beaufort Sea) and in regions of high nutrient availability and marine primary productivity (Barents Sea and Chukchi Sea). The combination of $\delta^{13} \mathrm{C}$ and $\Delta^{14} \mathrm{C}$ isotope values delineates large-scale differences in OC sources. Values of $\delta^{13} \mathrm{C}$-OC close to marine OC $(-21 \%$; Fry and Sherr, 1989) and $\Delta^{14} \mathrm{C}$ reflecting contemporary carbon are consistent with high marine primary productivity in the Barents Sea and Chukchi Sea. The Kara Sea receives input from major West Siberian catchments ( $\mathrm{Ob}$ and Yenisey rivers), with sediment $\mathrm{OC}$ that appears to reflect $\mathrm{OC}$ from contemporary terrestrial sources $(\sim-27 \%$; Fry and Sherr, 1989). By contrast, the terrigenous OC fraction in the Laptev and East Siberian seas is much older with a presumably substantial contribution from remobilization of thawing permafrost or other old deposits via erosional or fluvial processes (Figs. 1,2). These and other features can now be investigated through CASCADE in greater quantitative detail over large intra- and inter-system scales.

\section{Data availability}

CASCADE will be hosted and actively updated and extended by a database management at the Bolin Centre for Climate Research at Stockholm University. CASCADE is accessible at the Bolin Centre Database (https://doi.org/10.17043/cascade; Martens et al., 2021). When using the CASCADE, this paper and the database should be cited. The website also includes contact details, which can be used to submit new data for incorporation into future versions of CASCADE - a community effort and resource.

\section{Vision and future development}

CASCADE is the largest and most comprehensive openaccess database of OC parameters for Arctic Ocean sedi- 
ments. It is a resource that can facilitate a wide range of investigations on $\mathrm{OC}$ cycling in the high northern latitudes. For instance, CASCADE may help research on sources of organic matter, marine primary production, OC degradation, and OC transport both in the offshore direction and vertically from the sea surface to the sediment, and all this from both the contemporary and the historical perspectives. CASCADE provides opportunities to expand our still limited understanding of how sensitive terrestrial permafrost in different circum-Arctic regions is towards remobilization in both the current and earlier periods of rapid climate change. Future versions of CASCADE may also expand on parameters by adding more compound classes of terrestrial biomarkers, marine biomarkers, environmental contaminants (e.g., $\mathrm{Hg}$ and organic legacy and emerging substances) and others to investigate biogeochemical distribution and the fate of these in the Arctic Ocean.

Supplement. The supplement related to this article is available online at: https://doi.org/10.5194/essd-13-2561-2021-supplement.

Author contributions. The CASCADE database was conceptualized and planned by a team led by ÖG, IS and ER. JM, NB, BW and ÖG developed the technical framework of CASCADE. JM executed the development of CASCADE, populated the database with published and unpublished data from the literature and internal records, coordinated gap-filling analyses, and created maps. JM drafted and coordinated the manuscript in close collaboration with ÖG and BW. All authors contributed to the realization of the CASCADE database and participated in the editing of the manuscript.

Competing interests. The authors declare that they have no conflict of interest.

Acknowledgements. We thank collaborators throughout and beyond the International Siberian Shelf Study (ISSS) network and all participants of the Arctic Partner Forum 2018 for their advice in constructing the CASCADE database and for pointing out data sources during the development of the database. We also thank the crew and the scientific party of the ISSS-08 expedition on board RV Yacob Smirnitskyi, the SWERUS-C3 expedition on board the IB Oden in 2014 and various other field campaigns organized by the ISSS in 2004, 2005, 2007, 2008, 2011, 2016 and 2017. Furthermore, Lisa Bröder and Rickard Wennström are thanked for their help with gap-filling analysis of lignin phenols. We also thank August Andersson and Henry Holmstrand for their long-term assistance and advice during various field campaigns, laboratory analyses and computer-based work that contributed to the realization of this database.

Financial support. Development of CASCADE was supported by the European Research Council (ERC Advanced Grant CC-
TOP 695331 to Örjan Gustafsson), the EU H2020-funded project Nunataryuk (grant 773421), and the Swedish Research Council (grant 2017-01601). Field campaigns to obtain gap-filling samples were supported by the Knut and Alice Wallenberg Foundation (KAW contract 2011.0027 to Örjan Gustafsson) as part of the SWERUS-C3 program, as well as by the Russian Science Foundation (grant 21-77-30001 to Igor Semiletov) and the Russian Ministry of Science and Higher Education (grant 0211-2021-0010 to Pacific Oceanological Institute, Vladivostok). Furthermore, this study was supported by the assignment of the Russian Academy of Sciences (grant 0128-2021-0005) and the Russian Science Foundation (grant 18-05-60214) to the Shirshov Institute of Oceanology (Evgeny Romankevich, Alexander Vetrov). The collection of sample material in the Barents Sea was supported by the Research Council of Norway (grant 228107 to Michael L. Carroll; grant 223259) and VISTA (grant 6172 to Emmelie K. L. Åström). Gapfilling samples from the Canadian Arctic were supported by the Research Council of Canada (NSERC Discovery Grant RGPIN-201605457 to Anna J. Pieńkowski). Bart van Dongen was supported by an NERC research grant (NE/I024798/1) and Jorien Vonk was supported by the Dutch-NWO (Veni grant 863.12 .004 ).

Review statement. This paper was edited by Jens Klump and reviewed by Gerrit Müller and one anonymous referee.

\section{References}

AMAP: Snow, Water, Ice and Permafrost in the Arctic (SWIPA) 2017, Arctic Monitoring and Assessment Programme (AMAP), Oslo, Norway, 2017.

Belicka, L. L., Macdonald, R. W., Yunker, M. B., and Harvey, H. R.: The role of depositional regime on carbon transport and preservation in Arctic Ocean sediments, Mar. Chem., 86, 65-88, https://doi.org/10.1016/j.marchem.2003.12.006, 2004.

Berner, R. A.: Burial of organic carbon and pyrite sulfur in the modern ocean: Its geochemical and environmental significance, Am. J. Sci., 282, 451-473, https://doi.org/10.2475/ajs.282.4.451, 1982.

Biskaborn, B. K., Smith, S. L., Noetzli, J., Matthes, H., Vieira, G., Streletskiy, D. A., Schoeneich, P., Romanovsky, V. E., Lewkowicz, A. G., Abramov, A., Allard, M., Boike, J., Cable, W. L., Christiansen, H. H., Delaloye, R., Diekmann, B., Drozdov, D., Etzelmüller, B., Grosse, G., Guglielmin, M., Ingeman-Nielsen, T., Isaksen, K., Ishikawa, M., Johansson, M., Johannsson, H., Joo, A., Kaverin, D., Kholodov, A., Konstantinov, P., Kröger, T., Lambiel, C., Lanckman, J.-P., Luo, D., Malkova, G., Meiklejohn, I., Moskalenko, N., Oliva, M., Phillips, M., Ramos, M., Sannel, A. B. K., Sergeev, D., Seybold, C., Skryabin, P., Vasiliev, A., Wu, Q., Yoshikawa, K., Zheleznyak, M., and Lantuit, H.: Permafrost is warming at a global scale, Nat. Commun., 10, 264, https://doi.org/10.1038/s41467-018-08240-4, 2019.

Bröder, L., Tesi, T., Salvadó, J. A., Semiletov, I. P., Dudarev, O. V., and Gustafsson, Ö.: Fate of terrigenous organic matter across the Laptev Sea from the mouth of the Lena River to the deep sea of the Arctic interior, Biogeosciences, 13, 5003-5019, https://doi.org/10.5194/bg-13-5003-2016, 2016. 
Bröder, L., Tesi, T., Andersson, A., Semiletov, I., and Gustafsson, Ö.: Bounding the role of cross-shelf transport and degradation in land-ocean carbon transfer, Nat. Commun., 9, 806, https://doi.org/10.1038/s41467-018-03192-1, 2018.

van Dongen, B. E., Semiletov, I., Weijers, J. W. H., and Gustafsson, Ö.: Contrasting lipid biomarker composition of terrestrial organic matter exported from across the Eurasian Arctic by the five great Russian Arctic rivers, Global Biogeochem. Cy., 22, GB1011, https://doi.org/10.1029/2007GB002974, 2008.

Drenzek, N. J., Montluçon, D. B., Yunker, M. B., Macdonald, R. W., and Eglinton, T. I.: Constraints on the origin of sedimentary organic carbon in the Beaufort Sea from coupled molecular 13C and 14C measurements, Mar. Chem., 103, 146-162, https://doi.org/10.1016/j.marchem.2006.06.017, 2007.

Eglinton, G. and Hamilton, R. J.: Leaf Epicuticular Waxes, Science, 156, 1322-1335, https://doi.org/10.1126/science.156.3780.1322, 1967.

Fahl, K. and Stein, R.: Modern organic carbon deposition in the Laptev Sea and the adjacent continental slope: Surface water productivity vs. terrigenous input, Org. Geochem., 26, 379-390, https://doi.org/10.1016/S0146-6380(97)00007-7, 1997.

Feng, X., Vonk, J. E., van Dongen, B. E., Gustafsson, Ö., Semiletov, I. P., Dudarev, O. V, Wang, Z., Montluçon, D. B., Wacker, L., and Eglinton, T. I.: Differential mobilization of terrestrial carbon pools in Eurasian Arctic river basins, P. Natl. Acad. Sci. USA, 110, 14168-14173, https://doi.org/10.1073/pnas.1307031110, 2013.

Fry, B. and Sherr, E. B.: $\delta^{13}$ C Measurements as Indicators of Carbon Flow in Marine and Freshwater Ecosystems, in: Stable Isotopes in Ecological Research, Ecological Studies (Analysis and Synthesis), Springer, New York, NY, 196-229, 1989.

Goñi, M. A. and Montgomery, S.: Alkaline $\mathrm{CuO}$ Oxidation with a Microwave Digestion System: Lignin Analyses of Geochemical Samples, Anal. Chem., 72, 3116-3121, https://doi.org/10.1021/ac991316w, 2000.

Goñi, M. A., Yunker, M. B., MacDonald, R. W., and Eglinton, T. I.: Distribution and sources of organic biomarkers in arctic sediments from the Mackenzie River and Beaufort Shelf, Mar. Chem., 71, 23-51, https://doi.org/10.1016/S03044203(00)00037-2, 2000.

Goñi, M. A., Yunker, M. B., Macdonald, R. W., and Eglinton, T. I.: The supply and preservation of ancient and modern components of organic carbon in the Canadian Beaufort Shelf of the Arctic Ocean, Mar. Chem., 93, 53-73, https://doi.org/10.1016/j.marchem.2004.08.001, 2005.

Goñi, M. A., O’Connor, A. E., Kuzyk, Z. Z., Yunker, M. B., Gobeil, C., and Macdonald, R. W.: Distribution and sources of organic matter in surface marine sediments across the North American Arctic margin, J. Geophys. Res.-Ocean., 118, 4017-4035, https://doi.org/10.1002/jgrc.20286, 2013.

Grebmeier, J. M., Cooper, L. W., Feder, H. M., and Sirenko, B. I.: Ecosystem dynamics of the Pacific-influenced Northern Bering and Chukchi Seas in the Amerasian Arctic, Prog. Oceanogr., 71, 331-361, https://doi.org/10.1016/j.pocean.2006.10.001, 2006.

Gribov, A. and Krivoruchko, K.: Empirical Bayesian kriging implementation and usage, Sci. Total Environ., 722, 137290, https://doi.org/10.1016/j.scitotenv.2020.137290, 2020.

Guo, L., Semiletov, I., Gustafsson, Ö., Ingri, J., Andersson, P., Dudarev, O., and White, D.: Characterization of
Siberian Arctic coastal sediments: Implications for terrestrial organic carbon export, Global Biogeochem. Cy., 18, GB1036, https://doi.org/10.1029/2003gb002087, 2004.

Gustafsson, Ö., van Dongen, B. E., Vonk, J. E., Dudarev, O. V., and Semiletov, I. P.: Widespread release of old carbon across the Siberian Arctic echoed by its large rivers, Biogeosciences, 8, 1737-1743, https://doi.org/10.5194/bg-8-1737-2011, 2011.

Hedges, J. I. and Keil, R. G.: Sedimentary organic matter preservation: an assessment and speculative synthesis, Mar. Chem., 49, 81-115, https://doi.org/10.1016/0304-4203(95)00008-F, 1995.

Hedges, J. I. and Mann, D. C.: The characterization of plant tissues by their lignin oxidation products, Geochim. Cosmochim. Acta, 43, 1803-1807, https://doi.org/10.1016/0016-7037(79)90028-0, 1979.

Hedges, J. I., Keil, R. G., and Benner, R.: What happens to terrestrial organic matter in the ocean?, in: Organic Geochemistry, Pergamon, 27, 195-212, 1997.

Hugelius, G., Strauss, J., Zubrzycki, S., Harden, J. W., Schuur, E. A. G., Ping, C.-L., Schirrmeister, L., Grosse, G., Michaelson, G. J., Koven, C. D., O’Donnell, J. A., Elberling, B., Mishra, U., Camill, P., Yu, Z., Palmtag, J., and Kuhry, P.: Estimated stocks of circumpolar permafrost carbon with quantified uncertainty ranges and identified data gaps, Biogeosciences, 11, 6573-6593, https://doi.org/10.5194/bg-11-6573-2014, 2014.

Jakobsson, M.: Hypsometry and volume of the Arctic Ocean and its constituent seas, Geochem. Geophy. Geosy., 3, 1-18, https://doi.org/10.1029/2001GC000302, 2002.

Jakobsson, M., Mayer, L. A., Bringensparr, C., Castro, C. F., Mohammad, R., Johnson, P., Ketter, T., Accettella, D., Amblas, D., An, L., Arndt, J. E., Canals, M., Casamor, J. L., Chauché, N., Coakley, B., Danielson, S., Demarte, M., Dickson, M. L., Dorschel, B., Dowdeswell, J. A., Dreutter, S., Fremand, A. C., Gallant, D., Hall, J. K., Hehemann, L., Hodnesdal, H., Hong, J., Ivaldi, R., Kane, E., Klaucke, I., Krawczyk, D. W., Kristoffersen, Y., Kuipers, B. R., Millan, R., Masetti, G., Morlighem, M., Noormets, R., Prescott, M. M., Rebesco, M., Rignot, E., Semiletov, I., Tate, A. J., Travaglini, P., Velicogna, I., Weatherall, P., Weinrebe, W., Willis, J. K., Wood, M., Zarayskaya, Y., Zhang, T., Zimmermann, M., and Zinglersen, K. B.: The International Bathymetric Chart of the Arctic Ocean Version 4.0, Sci. Data, 7, 176, https://doi.org/10.1038/s41597-020-0520-9, 2020.

Karlsson, E., Gelting, J., Tesi, T., van Dongen, B., Andersson, A., Semiletov, I., Charkin, A., Dudarev, O., and Gustafsson, Ö.: Different sources and degradation state of dissolved, particulate, and sedimentary organic matter along the Eurasian Arctic coastal margin, Global Biogeochem. Cy., 30, 898-919, https://doi.org/10.1002/2015GB005307, 2016.

Lantuit, H., Overduin, P. P., Couture, N., Wetterich, S., Aré, F., Atkinson, D., Brown, J., Cherkashov, G., Drozdov, D., Donald Forbes, L., Graves-Gaylord, A., Grigoriev, M., Hubberten, H. W., Jordan, J., Jorgenson, T., Ødegård, R. S., Ogorodov, S., Pollard, W. H., Rachold, V., Sedenko, S., Solomon, S., Steenhuisen, F., Streletskaya, I., and Vasiliev, A.: The Arctic Coastal Dynamics Database: A New Classification Scheme and Statistics on Arctic Permafrost Coastlines, Estuar. Coast., 35, 383-400, https://doi.org/10.1007/s12237-010-9362-6, 2012.

Lenton, T. M.: Arctic climate tipping points, Ambio, 41, 10-22, https://doi.org/10.1007/s13280-011-0221-x, 2012. 
Martens, J., Wild, B., Pearce, C., Tesi, T., Andersson, A., Bröder, L., O'Regan, M., Jakobsson, M., Sköld, M., Gemery, L., Cronin, T. M., Semiletov, I., Dudarev, O. V., and Gustafsson, Ö.: Remobilization of Old Permafrost Carbon to Chukchi Sea Sediments During the End of the Last Deglaciation, Global Biogeochem. Cy., 33, 2-14, https://doi.org/10.1029/2018GB005969, 2019.

Martens, J., Wild, B., Muschitiello, F., O'Regan, M., Jakobsson, M., Semiletov, I., Dudarev, O. V., and Gustafsson, Ö.: Remobilization of dormant carbon from Siberian-Arctic permafrost during three past warming events, Sci. Adv., 6, 6546-6562, https://doi.org/10.1126/sciadv.abb6546, 2020.

Martens, J., Romankevic, E., Semiletov, I., Wild, B., Dongen, B. van, Vonk, J., Tesi, T., Shakhova, N., Dudarev, O. V., Kosmach, D., Vetrov, A., Lobkovsky, L., Belyaev, N., Macdonald, R., Pieńkowski, A. J., Eglinton, T. I., Haghipour, N., Dahle, S., Carroll, M. L., Åström, E. K. L., Grebmeier, J. M., Cooper, L. W., Possnert, G., and Gustafsson, Ö.: The Circum-Arctic Sediment Carbon Database - CASCADE, version 1.0, Bolin Centre Database, https://doi.org/10.17043/cascade, 2021.

Meredith, M., Sommerkorn, M., Cassotta, S., Derksen, C., Ekaykin, A., Hollowed, A., Kofinas, G., Mackintosh, A., MelbourneThomas, J., Muelbert, M. M. C., Ottersen, G., Pritchard, H., and Schuur, E. A. G.: Polar Regions, chap. 3, in: IPCC Special Report on the Ocean and Cryosphere in a Changing Climate, edited by: Pörtner, H.-O., Roberts, D. C., Masson-Delmotte, V., Zhai, P., Tignor, M., Poloczanska, E., Mintenbeck, K., Alegría, A., Nicolai, M., Okem, A., Petzold, J., Rama, B., Weyer, N. M., IPCC, 2019.

Mueller-Lupp, T., Bauch, H. A., Erlenkeuser, H., Hefter, J., Kassens, H., and Thiede, J.: Changes in the deposition of terrestrial organic matter on the Laptev Sea shelf during the Holocene: evidence from stable carbon isotopes, Int. J. Earth Sci., 89, 563 568, https://doi.org/10.1007/s005310000128, 2000.

Muschitiello, F., O’Regan, M., Martens, J., West, G., Gustafsson, Ö., and Jakobsson, M.: A new 30000-year chronology for rapidly deposited sediments on the Lomonosov Ridge using bulk radiocarbon dating and probabilistic stratigraphic alignment, Geochronology, 2, 81-91, https://doi.org/10.5194/gchron2-81-2020, 2020.

Naidu, A. S., Scalan, R. S., Feder, H. M., Goering, J. J., Hameedi, M. J., Parker, P. L., Behrens, E. W., Caughey, M. E., and Jewett, S. C.: Stable organic carbon isotopes in sediments of the north Bering-south Chukchi seas, Alaskan-Soviet Arctic Shelf, Cont. Shelf Res., 13, 669-691, https://doi.org/10.1016/02784343(93)90099-J, 1993.

Naidu, A. S., Cooper, L. W., Finney, B. P., Macdonald, R. W., Alexander, C., and Semiletov, I. P.: Organic carbon isotope ratio $(\delta 13 \mathrm{C})$ of Arctic Amerasian Continental shelf sediments, Int. J. Earth Sci., 89, 522-532, https://doi.org/10.1007/s005310000121, 2000.

Obu, J., Westermann, S., Bartsch, A., Berdnikov, N., Christiansen, H. H., Dashtseren, A., Delaloye, R., Elberling, B., Etzelmüller, B., Kholodov, A., Khomutov, A., Kääb, A., Leibman, M. O., Lewkowicz, A. G., Panda, S. K., Romanovsky, V., Way, R. G., Westergaard-Nielsen, A., Wu, T., Yamkhin, J., and Zou, D.: Northern Hemisphere permafrost map based on TTOP modelling for 2000-2016 at $1 \mathrm{~km}^{2}$ scale, Earth-Sci. Rev., 193, 299-316, https://doi.org/10.1016/j.earscirev.2019.04.023, 2019.
Romankevich, E. A.: Geochemistry of Organic Matter in the Ocean, Springer Berlin Heidelberg, Berlin, Heidelberg, https://doi.org/10.1007/978-3-642-49964-7, 1984.

Semiletov, I. and Gustafsson, Ö.: East Siberian shelf study alleviates scarcity of observations, Eos, 90, 145-146, https://doi.org/10.1029/2009eo170001, 2009.

Semiletov, I., Dudarev, O., Luchin, V., Charkin, A., Shin, K. H., and Tanaka, N.: The East Siberian Sea as a transition zone between Pacific-derived waters and Arctic shelf waters, Geophys. Res. Lett., 32, L10614, https://doi.org/10.1029/2005GL022490, 2005.

Semiletov, I., Pipko, I., Gustafsson, Ö., Anderson, L. G., Sergienko, V., Pugach, S., Dudarev, O., Charkin, A., Gukov, A., Bröder, L., Andersson, A., Spivak, E., and Shakhova, N.: Acidification of East Siberian Arctic Shelf waters through addition of freshwater and terrestrial carbon, Nat. Geosci., 9, 361-365, https://doi.org/10.1038/NEGO2695, 2016.

Sparkes, R. B., Doğrul Selver, A., Bischoff, J., Talbot, H. M., Gustafsson, Ö., Semiletov, I. P., Dudarev, O. V., and van Dongen, B. E.: GDGT distributions on the East Siberian Arctic Shelf: implications for organic carbon export, burial and degradation, Biogeosciences, 12, 3753-3768, https://doi.org/10.5194/bg-123753-2015, 2015.

Stein, R. and Macdonald, R. W. (Eds.): The Organic Carbon Cycle in the Arctic Ocean, Springer, Berlin, Heidelberg, https://doi.org/10.1007/978-3-642-18912-8, 2004.

Stein, R., Grobe, H., and Wahsner, M.: Organic carbon, carbonate, and clay mineral distributions in eastern central Arctic Ocean surface sediments, Mar. Geol., 119, 269-285, https://doi.org/10.1016/0025-3227(94)90185-6, 1994.

Stein, R., Macdonald, R. W., Naidu, A. S., Yunker, M. B., Gobeil, C., Cooper, L. W., Grebmeier, J. M., Whitledge, T. E., Hameedi, M. J., Petrova, V. I., Batova, G. I., Zinchenko, A. G., Kursheva, A. V, Narkevskiy, E. V, Fahl, K., Vetrov, A., Romankevich, E. A., Birgel, D., Schubert, C., Harvey, H. R., and Weiel, D.: Organic Carbon in Arctic Ocean Sediments: Sources, Variability, Burial, and Paleoenvironmental Significance, in: The Organic Carbon Cycle in the Arctic Ocean, edited by: Stein, R. and MacDonald, R. W., Springer, Berlin, Heidelberg, 169-314, 2004.

Stenström, K. E., Skog, G., Georgiadou, E., Genberg, J., and Johansson, A.: A guide to radiocarbon units and calculations, Lund University, Nuclear Physics, 2011.

Stuiver, M. and Polach, H. A.: Discussion Reporting of ${ }^{14} \mathrm{C}$ Data, Radiocarbon, 19, 355-363, https://doi.org/10.1017/S0033822200003672, 1977.

Tesi, T., Semiletov, I., Hugelius, G., Dudarev, O., Kuhry, P., and Gustafsson, Ö.: Composition and fate of terrigenous organic matter along the Arctic land-ocean continuum in East Siberia: Insights from biomarkers and carbon isotopes, Geochim. Cosmochim. Acta, 133, 235-256, https://doi.org/10.1016/j.gca.2014.02.045, 2014.

Tesi, T., Muschitiello, F., Smittenberg, R. H., Jakobsson, M., Vonk, J. E., Hill, P., Andersson, A., Kirchner, N., Noormets, R., Dudarev, O. V., Semiletov, I. P., and Gustafsson, Ö.: Massive remobilization of permafrost carbon during post-glacial warming, Nat. Commun., 7, 13653, https://doi.org/10.1038/ncomms13653, $2016 a$.

Tesi, T., Semiletov, I., Dudarev, O., Andersson, A., and Gustafsson, Ö.: Matrix association effects on hydrodynamic sorting and 
degradation of terrestrial organic matter during cross-shelf transport in the Laptev and East Siberian shelf seas, J. Geophys. Res.Biogeo., 121, 731-752, https://doi.org/10.1002/2015JG003067, 2016 b.

Vetrov, A. A. and Romankevich, E. A.: Carbon Cycle in the Russian Arctic Seas, Springer, Berlin, Heidelberg, 2004.

Vonk, J., Sánchez-García, L., van Dongen, B. E., Alling, V., Kosmach, D., Charkin, A., Semiletov, I. P., Dudarev, O. V, Shakhova, N., Roos, P., Eglinton, T. I., Andersson, A., Gustafsson, Ö., and Gustafsson, O.: Activation of old carbon by erosion of coastal and subsea permafrost in Arctic Siberia, Nature, 489, 137-140, https://doi.org/10.1038/nature11392, 2012.

Vonk, J. E. and Gustafsson, Ö.: Permafrost-carbon complexities, Nat. Geosci., 6, 675-676, https://doi.org/10.1038/ngeo1937, 2013.

Vonk, J. E., Sánchez-García, L., Semiletov, I., Dudarev, O., Eglinton, T., Andersson, A., and Gustafsson, Ö.: Molecular and radiocarbon constraints on sources and degradation of terrestrial organic carbon along the Kolyma paleoriver transect, East Siberian Sea, Biogeosciences, 7, 3153-3166, https://doi.org/10.5194/bg7-3153-2010, 2010.
Vonk, J. E., Semiletov, I. P., Dudarev, O. V, Eglinton, T. I., Andersson, A., Shakhova, N., Charkin, A., Heim, B., and Gustafsson, Ö.: Preferential burial of permafrost-derived organic carbon in Siberian-Arctic shelf waters, J. Geophys. Res.-Ocean., 119, 8410-8421, https://doi.org/10.1002/2014JC010261, 2014.

Xiao, X., Fahl, K., Müller, J., and Stein, R.: Sea-ice distribution in the modern Arctic Ocean: Biomarker records from trans-Arctic Ocean surface sediments, Geochim. Cosmochim. Acta, 155, 1629, https://doi.org/10.1016/j.gca.2015.01.029, 2015.

Yunker, M. B., Belicka, L. L., Harvey, H. R., and Macdonald, R. W.: Tracing the inputs and fate of marine and terrigenous organic matter in Arctic Ocean sediments: A multivariate analysis of lipid biomarkers, Deep-Res. Pt. II, 52, 3478-3508, https://doi.org/10.1016/j.dsr2.2005.09.008, 2005. 